\title{
Utilization of Silicon Fertilizer Application on Pepper Seedling Production
}

\author{
Eakkarin SUKKAEW $^{1}$, Suphachai AMKHA ${ }^{1}$, Tawatchai INBOONCHOY ${ }^{1} \&$ Thongchai MALA $^{1}$ \\ ${ }^{1}$ Department of Soil Science, Faculty of Agriculture at Kamphaeng Saen, Kasetsart University, Thailand \\ Correspondence: Suphachai AMKHA, Department of Soil Science, Faculty of Agriculture at Kamphaeng Saen, \\ Kasetsart University, Kamphaeng Saen Campus, Nakhon Pathom, 73140, Thailand. E-mail: agrscak@ku.ac.th
}

Received: July 29, 2016

Accepted: August 8, 2016

Online Published: October 26, 2016

doi:10.5539/mas.v10n11p264

URL: http://dx.doi.org/10.5539/mas.v10n11p264

\begin{abstract}
The purpose of this research was study the rate and application method of calcium silicate $\left(\mathrm{Ca}_{2} \mathrm{SiO}_{4}\right)$ fertilizer appropriated for pepper seedling production. This study was divided into two experiments. Experiment 1 , the effect of $\mathrm{Ca}_{2} \mathrm{SiO}_{4}$ fertilizer application in pepper seedling by mixed in growing media was arranged in $2 \times 6$ factorials in Completely Randomized Design (CRD) with 4 replications. Factor A was seed preparation methods (seed primed with $\mathrm{Ca}_{2} \mathrm{SiO}_{4}$ fertilizer at a rate $2 \mathrm{~g} \mathrm{~L}^{-1}$ and non-seed primed) and factor $\mathrm{B}$ was application rates of $\mathrm{Ca}_{2} \mathrm{SiO}_{4}$ fertilizer at $0,30,60,120,240$ and $480 \mathrm{~kg} \mathrm{ha}^{-1}$. Experiment 2, the effect of $\mathrm{Ca}_{2} \mathrm{SiO}_{4}$ fertilizer application in pepper seedling by foliar method was arranged in $2 \times 6$ factorials in CRD with 4 replications. Factor A was seed preparation methods and factor $\mathrm{B}$ was application rates of $\mathrm{Ca}_{2} \mathrm{SiO}_{4}$ fertilizer at $0,2,4,6,8$ and $10 \mathrm{~g} \mathrm{~L}^{-1}$. All experiments data were collected such as plant growth and total silicon content in plant at 28 days after sowing (DAS). From experiment 1, the results showed that seed primed with $\mathrm{Ca}_{2} \mathrm{SiO}_{4}$ fertilizer application at a rate 120 $\mathrm{kg} \mathrm{ha}^{-1}$ gave the good plant growth and total silicon in plant. Experiment 2, the results showed that seed primed with $\mathrm{Ca}_{2} \mathrm{SiO}_{4}$ fertilizer application at a rate $2 \mathrm{~g} \mathrm{~L}^{-1}$ gave the highest of plant growth and total silicon in plant. To conclude, $\mathrm{Ca}_{2} \mathrm{SiO}_{4}$ fertilizer application can be employed for enhancing plant growth of pepper seedling and increasing silicon content in plant.
\end{abstract}

Keywords: foliar, fertilizer, pepper seedling, silicon, mixed in growing media

\section{Introduction}

Pepper (Capsicum sp.) is the fruit of plants from the genus Capsicum, and family, Solanaceae. Pepper is a high nutrition value and consists of a protein, vitamin and mineral. Peppers are a rich source of spicy-hot capsaicin. They are also very high in antioxidant carotenoids, which are linked with numerous health benefits. Capsaicin is a one of the most studied plant compounds in peppers. It is responsible for their pungent (hot) flavor and many of their health effects. Pepper is a vegetable popular consumption in Thailand. It can be seen that pepper was composed in many Thai foods. It very famous in Thai people because high antioxidant and it can be improves the good health. In Thailand, the area plantation pepper it found that in the northern part and northeastern part. In 2015, pepper area plantation was $31,000 \mathrm{ha}^{-1}$ and trend to decreasing from $2010\left(56,570 \mathrm{ha}^{-1}\right)$ (Department of Agriculture, 2015). The reason for the decline of area because farmer change plant for cultivate and pepper yield less quality destruction caused by disease and insects, also low seed quality and expensive seed. Total pepper yield production in Thailand was 0.25 tons ha $^{-1}$ and crop removal in pepper amount of $1.04 \mathrm{~kg} \mathrm{Si} \mathrm{ha}^{-1}(2.23 \mathrm{~kg}$ $\mathrm{SiO}_{2} \mathrm{ha}^{-1}$ ) (Department of Agriculture, 2015). Then, silicon ( $\mathrm{Si}$ ) is necessary for pepper, because Si loss of crop removal and therefore Si not enough for pepper and soil. So that we must add Si for pepper, since preparation seed, seedling and add direct in soil. Also, $\mathrm{Si}$ is the second most abundant element on the surface of the earth. It is not considered to be an essential element for higher plant (Neumann et al., 2001). Si can be classified as beneficial element (Epstein, 2005). Si in soil solution is mainly present in the form of an uncharged monomeric molecule, silicic acid. Many plants show the better growth as the $\mathrm{Si}$ form available $\left(\mathrm{H}_{4} \mathrm{SiO}_{4}\right.$ or $\left.\mathrm{SiO}_{4}{ }^{2-}\right)$. $\mathrm{Si}$ is reported to the component of cell (Ma et al., 2001), improve plant resistance to a range of biotic and abiotic stresses (Ma \& Yamaji, 2006), stimulate on growth and yield (Ma \& Takahashi, 2002), leaf erectness, haulm stability and lodging and increase photosynthesis (Epstein \& Bloom, 2005). In addition, calcium (Ca) is relatively abundant in soil and rarely limits corps production. It makes up about $3.6 \%$ of earth's crust. It present in soil minerals such as amphibole, apatite, calcite, dolomite and feldspar. $\mathrm{Ca}$ is a component of cell wall and is 
also important for cell division and elongation permeability of cell membranes. Moreover, seed priming is a pre-sowing treatment in which seeds are soaked in osmotic that allows the seeds to imbibe water and go through the first stages of germination. In addition, seed priming enhanced germination speed and uniformity of seeds (McDonald, 2000). The primed seed increase germination speed and uniformity of seeds and gave the good seedling. It can be improve the growth rate and yield in pepper production. Now, utilization of Si fertilizer has many variants. Kunlinda et al., (2014) reported that sweet pepper "vega 1288" seeds were primed with $\mathrm{Ca}_{2} \mathrm{SiO}_{4}$ at $2 \mathrm{~g} \mathrm{~L}^{-1}$ gave the highest of germination index $(\mathrm{GI})$ and germination percentage. While, seed-primed with $\mathrm{Ca}_{2} \mathrm{SiO}_{4}$ at $4 \mathrm{~g} \mathrm{~L}^{-1}$ by foliar application gave the good of sweet pepper seedling. From the above, thus purpose of this research was to study the rate and application method of $\mathrm{Ca}_{2} \mathrm{SiO}_{4}$ fertilizer appropriated for pepper seedling production.

\section{Methods}

The experiment was conducted in greenhouse at soil science experimental field, Department of Soil Science, Faculty of Agriculture at Kamphaeng Saen, Kasetsart University, Nakhon Pathom, Thailand. The each experiment was used peat for cultivated. In addition, $\mathrm{Si}$ fertilizer is a calcium silicate $\left(\mathrm{Ca}_{2} \mathrm{SiO}_{4}\right)$ and calcium silicate used in this experiment was component as silicon $\left(25 \% \mathrm{SiO}_{2}\right)$, calcium $(40 \% \mathrm{CaO})$ and magnesium $(2 \% \mathrm{MgO})$. This study was divided into two experiments. The effect of $\mathrm{Ca}_{2} \mathrm{SiO}_{4}$ fertilizer application in pepper seedling by mixed in growing media (experiment 1) was used $2 \times 6$ factorials in Completely Randomized Design (CRD) with 4 replications. Factor A was seed preparation methods (seed primed with $\mathrm{Ca}_{2} \mathrm{SiO}_{4}$ fertilizer at a rate $2 \mathrm{~g} \mathrm{~L}^{-1}$ and non-seed primed) and factor B was application rates of $\mathrm{Ca}_{2} \mathrm{SiO}_{4}$ fertilizer at $0,30,60,120,240$ and $480 \mathrm{~kg} \mathrm{ha}^{-1}$. The effect of $\mathrm{Ca}_{2} \mathrm{SiO}_{4}$ fertilizer application in pepper seedling by foliar method (experiment 2) was used 2x6 factorials in CRD with 4 replications. Factor A was seed preparation methods (seed primed with $\mathrm{Ca}_{2} \mathrm{SiO}_{4}$ fertilizer at a rate $2 \mathrm{~g} \mathrm{~L}^{-1}$ and non-seed primed) and factor $\mathrm{B}$ was application rates of $\mathrm{Ca}_{2} \mathrm{SiO}_{4}$ fertilizer at $0,2,4,6,8$ and $10 \mathrm{~g} \mathrm{~L}^{-1}$. All treatments used foliar $\mathrm{Ca}_{2} \mathrm{SiO}_{4}$ fertilizer for pepper seedling at 14 and 21 days after sowing (DAS).

\subsection{Seed Preparation Methods}

Chilli pepper seeds were primed with $\mathrm{Ca}_{2} \mathrm{SiO}_{4}$ fertilizer at a rate $2 \mathrm{~g} \mathrm{~L}^{-1}$ for 5 hours at temperate room (Kunlinda et al., 2014).

\subsection{Data Collection}

The plant samples were measured at 28 DAS. All experiments data were collected such as plant height, leaf number (larger than 1 centimeter), fresh and dry weight (Kunlinda et al., 2014). Total Si content in plant was using Nayer et al., (1975) method.

\subsection{Statistical Analysis}

The data were analyzed for Statistical analyses carried out using the R program. By method of analysis of variance (ANOVA) and Comparisons of the means among treatments were done using LSD at a significance level of $\mathrm{P}<0.01$.

\section{Results}

\subsection{Effect of $\mathrm{Ca}_{2} \mathrm{SiO}_{4}$ fertilizer application in pepper by mixed in growing media (Experiment 1)}

\subsubsection{Plant Height of Pepper Seedling}

Seed preparation methods showed that seed primed with $\mathrm{Ca}_{2} \mathrm{SiO}_{4}$ fertilizer application at a rate $2 \mathrm{~g} \mathrm{~L}^{-1}$ was significantly different and gave the plant height higher than non-seed-primed (Table1). In addition, $\mathrm{Ca}_{2} \mathrm{SiO}_{4}$ fertilizer application by mixed in growing media at a rate $120 \mathrm{~kg} \mathrm{ha}^{-1}$ was significantly different and gave to trend the plant height of pepper seedling (Table1). While, relationship between factor A (seed preparation methods) with factor $\mathrm{B}$ (application rate of $\mathrm{Ca}_{2} \mathrm{SiO}_{4}$ fertilizer) were significantly different that seed-primed with application rate of $\mathrm{Ca}_{2} \mathrm{SiO}_{4}$ fertilizer at $120 \mathrm{~kg} \mathrm{ha}^{-1}$ gave to trend the high of plant height (Table1). 
Table 1. Plant height $(\mathrm{cm})$ of pepper seedling at 28 day after sowing (experiment 1 )

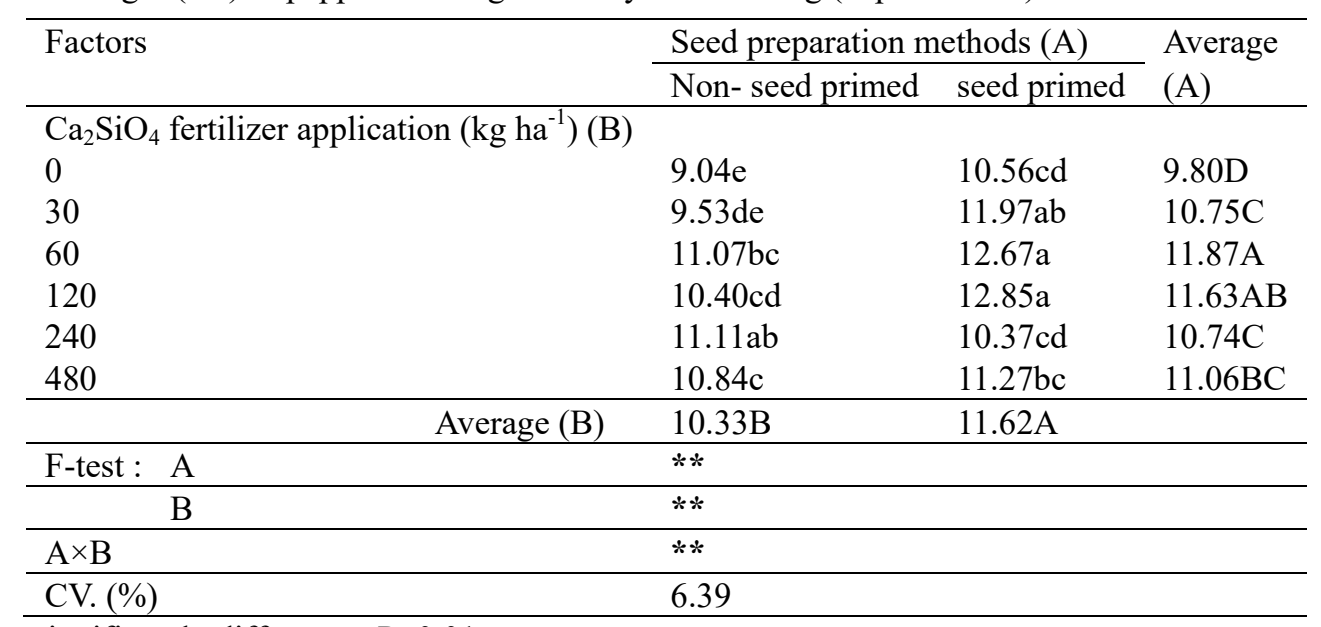

Note. $* *=$ significantly different at $\mathrm{P}<0.01$

\subsubsection{Leaf Number of Pepper}

The results showed that seed preparation methods and $\mathrm{Ca}_{2} \mathrm{SiO}_{4}$ fertilizer application by mixed in growing media were non significantly different of the leaf number of pepper (Table 2)

Table 2. Leaf number of pepper seedling at 28 day after sowing (experiment 1)

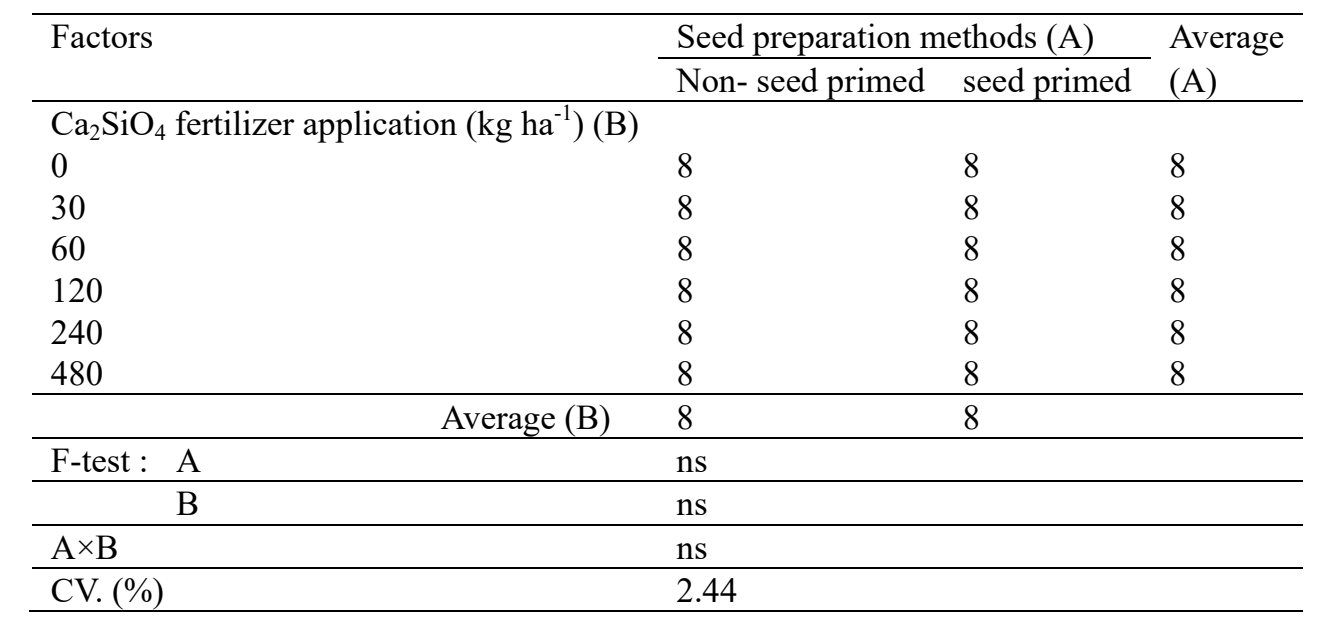

Note. $\mathrm{ns}=$ non-significantly different at $\mathrm{P}>0.01$

\subsubsection{Fresh Weight of Pepper Seedling}

The results showed that seed preparation methods were significantly different and seed primed gave the fresh weight higher than non-seed primed (Table3). $\mathrm{Ca}_{2} \mathrm{SiO}_{4}$ fertilizer application at a rate $240 \mathrm{~kg} \mathrm{ha}^{-1}$ was significantly different and gave to trend the fresh weight of pepper seedling (Table3). While, relationship between factor $\mathrm{A}$ with factor $\mathrm{B}$ were significantly different that seed primed with application rate of $\mathrm{Ca}_{2} \mathrm{SiO}_{4}$ fertilizer at $120 \mathrm{~kg} \mathrm{ha}^{-1}$ gave to trend the high of Fresh weight of pepper seedling (Table3). 
Table 3. Fresh weight (g) of pepper seedling at 28 day after sowing (experiment 1)

\begin{tabular}{|c|c|c|c|}
\hline \multirow[t]{2}{*}{ Factors } & \multicolumn{2}{|c|}{ Seed preparation methods (A) } & \multirow{2}{*}{$\begin{array}{l}\text { Average } \\
\text { (A) }\end{array}$} \\
\hline & Non- seed primed & seed primed & \\
\hline \multicolumn{4}{|l|}{$\mathrm{Ca}_{2} \mathrm{SiO}_{4}$ fertilizer application $\left(\mathrm{kg} \mathrm{ha}^{-1}\right)(\mathrm{B})$} \\
\hline 0 & $2.54 \mathrm{c}$ & $2.58 \mathrm{c}$ & $2.56 \mathrm{~B}$ \\
\hline 30 & $2.86 \mathrm{abc}$ & 2.84abc & $2.83 \mathrm{~A}$ \\
\hline 60 & $2.81 \mathrm{abc}$ & $1.97 \mathrm{~d}$ & $2.39 \mathrm{~B}$ \\
\hline 120 & $2.73 b c$ & $3.16 \mathrm{a}$ & $2.94 \mathrm{~A}$ \\
\hline 240 & $3.01 \mathrm{ab}$ & $2.94 \mathrm{abc}$ & $2.97 \mathrm{~A}$ \\
\hline 480 & $2.86 \mathrm{abc}$ & $3.02 \mathrm{ab}$ & $2.94 \mathrm{~A}$ \\
\hline Average (B) & $2.66 \mathrm{~B}$ & $2.89 \mathrm{~A}$ & \\
\hline F-test : A & $* *$ & & \\
\hline B & $* *$ & & \\
\hline $\mathrm{A} \times \mathrm{B}$ & $* *$ & & \\
\hline CV. (\%) & 8.72 & & \\
\hline
\end{tabular}

Note. $* *=$ significantly different at $\mathrm{P}<0.01$

\subsubsection{Dry Weight of Pepper Seedling}

The results showed that seed preparation methods was gave the same as the fresh weight (Table4), but $\mathrm{Ca}_{2} \mathrm{SiO}_{4}$ fertilizer application at a rate $120 \mathrm{~kg} \mathrm{ha}^{-1}$ was significantly different and gave to trend the dry weight of pepper seedling (Table4). While, relationship between factor A with factor B were significantly different that seed primed with application rate of $\mathrm{Ca}_{2} \mathrm{SiO}_{4}$ fertilizer at $120 \mathrm{~kg} \mathrm{ha}^{-1}$ gave to trend the high of dry weight of pepper seedling (Table4).

Table 4. Dry weight (g) of pepper seedling at 28 day after sowing (experiment 1 )

\begin{tabular}{|c|c|c|c|}
\hline \multirow{2}{*}{ Factors } & \multicolumn{2}{|c|}{ Seed preparation methods (A) } & \multirow{2}{*}{$\begin{array}{l}\text { Average } \\
\text { (A) }\end{array}$} \\
\hline & Non- seed primed & seed primed & \\
\hline $\mathrm{Ca}_{2} \mathrm{SiO}_{4}$ fertilizer application $\left(\mathrm{kg} \mathrm{ha}^{-1}\right)(\mathrm{B})$ & & & \\
\hline 0 & $0.25 \mathrm{~b}$ & $0.25 \mathrm{~b}$ & $0.24 \mathrm{~B}$ \\
\hline 30 & $0.26 \mathrm{~b}$ & $0.28 \mathrm{ab}$ & $0.26 \mathrm{AB}$ \\
\hline 60 & $0.24 \mathrm{~b}$ & $0.26 \mathrm{ab}$ & $0.21 \mathrm{C}$ \\
\hline 120 & $0.17 \mathrm{c}$ & $0.31 \mathrm{a}$ & $0.28 \mathrm{~A}$ \\
\hline 240 & $0.29 \mathrm{ab}$ & $0.25 b$ & $0.27 \mathrm{AB}$ \\
\hline 480 & $0.35 \mathrm{~b}$ & $0.27 \mathrm{ab}$ & $0.25 \mathrm{AB}$ \\
\hline Average (B) & $0.24 \mathrm{~B}$ & $0.27 \mathrm{~A}$ & \\
\hline F-test : A & $* *$ & & \\
\hline $\mathrm{B}$ & $* *$ & & \\
\hline $\mathrm{A} \times \mathrm{B}$ & $* *$ & & \\
\hline 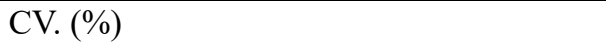 & 11.31 & & \\
\hline
\end{tabular}

\subsubsection{Total Silicon Content in Pepper Seedling}

Our treatments results demonstrated that in total silicon, seed preparation methods the results showed that was non significantly different of total silicon in pepper seedling (Table5). In addition, $\mathrm{Ca}_{2} \mathrm{SiO}_{4}$ fertilizer application at a rate $480 \mathrm{~kg} \mathrm{ha}^{-1}$ was significantly different and gave to trend the total silicon in pepper seedling (Table5). While, relationship between factor A with factor B were significantly different that seed primed with application rate of $\mathrm{Ca}_{2} \mathrm{SiO}_{4}$ fertilizer at $480 \mathrm{~kg} \mathrm{ha}^{-1}$ gave to trend the total silicon in pepper seedling (Table5). 
Table 5. Total silicon content $\left(\mathrm{mg} \mathrm{kg}^{-1}\right)$ in pepper seedling at 28 day after sowing (experiment 1 )

\begin{tabular}{|c|c|c|c|}
\hline \multirow[t]{2}{*}{ Factors } & \multicolumn{2}{|c|}{ Seed preparation methods (A) } & \multirow{2}{*}{$\begin{array}{l}\text { Average } \\
\text { (A) }\end{array}$} \\
\hline & Non- seed primed & seed primed & \\
\hline \multicolumn{4}{|c|}{$\mathrm{Ca}_{2} \mathrm{SiO}_{4}$ fertilizer application $\left(\mathrm{kg} \mathrm{ha}^{-1}\right)(\mathrm{B})$} \\
\hline 0 & $1.00 \mathrm{c}$ & $2.00 \mathrm{c}$ & $1.00 \mathrm{~b}$ \\
\hline 30 & $24.00 \mathrm{ab}$ & $17.00 \mathrm{~b}$ & $21.00 \mathrm{a}$ \\
\hline 60 & $25.00 \mathrm{ab}$ & $16.00 \mathrm{~b}$ & $20.00 \mathrm{a}$ \\
\hline 120 & $20.00 \mathrm{~b}$ & $22.00 \mathrm{~b}$ & $20.00 \mathrm{a}$ \\
\hline 240 & $21.00 \mathrm{~b}$ & $24.00 \mathrm{ab}$ & $22.00 \mathrm{a}$ \\
\hline \multirow[t]{2}{*}{480} & $17.00 \mathrm{~b}$ & $34.00 \mathrm{a}$ & $25.00 \mathrm{a}$ \\
\hline & 18.00 & 19.00 & \\
\hline F-test :A & ns & & \\
\hline $\mathrm{B}$ & $* *$ & & \\
\hline $\mathrm{A} \times \mathrm{B}$ & $* *$ & & \\
\hline CV. (\%) & 27.27 & & \\
\hline
\end{tabular}

Note. $=$ non-significantly different at $\mathrm{P}>0.01, * *=$ significantly different at $\mathrm{P}<0.01$

\subsection{The effect of $\mathrm{Ca}_{2} \mathrm{SiO}_{4}$ fertilizer application in pepper by foliar method (Experiment 2)}

\subsubsection{Plant Height of Pepper Seedling}

Seed preparation methods the results showed that seed primed with $\mathrm{Ca}_{2} \mathrm{SiO}_{4}$ fertilizer application at a rate $2 \mathrm{~g} \mathrm{~L}^{1}$ was significantly different and gave the plant height higher than non-seed primed (Table6). In addition, $\mathrm{Ca}_{2} \mathrm{SiO}_{4}$ fertilizer application by foliar method was non-significantly different of the plant height of pepper seedling (Table6). While, relationship between factor A with factor B were non-significantly different of plant height of pepper seedling (Table6).

Table 6. Plant height $(\mathrm{cm})$ of pepper seedling (experiment 2)

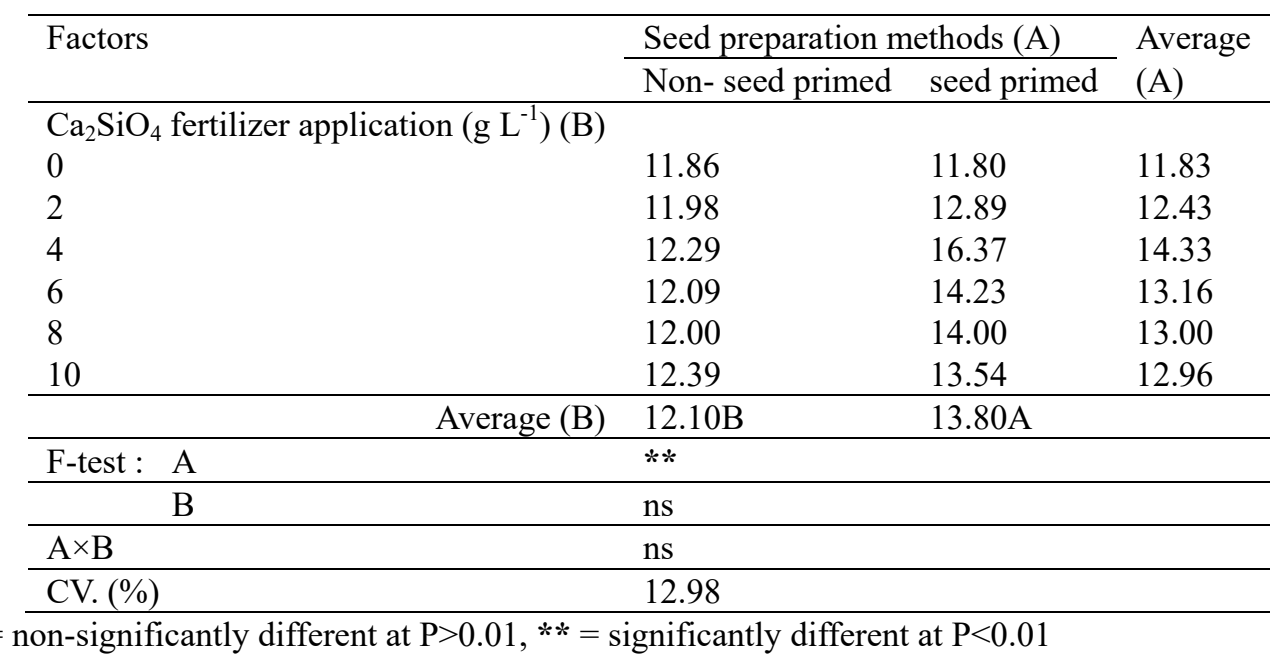

\subsubsection{Leaf Number of Pepper}

The results showed that seed preparation methods and $\mathrm{Ca}_{2} \mathrm{SiO}_{4}$ fertilizer application by foliar method were nonsignificantly different of the leaf number of pepper (Table 7). 
Table 7. Leaf number of pepper seedling (experiment 2)

\begin{tabular}{|c|c|c|c|}
\hline \multirow[t]{2}{*}{ Factors } & \multicolumn{2}{|c|}{ Seed preparation methods (A) } & \multirow{2}{*}{$\begin{array}{l}\text { Average } \\
\text { (A) }\end{array}$} \\
\hline & Non- seed primed & seed primed & \\
\hline \multicolumn{4}{|l|}{$\mathrm{Ca}_{2} \mathrm{SiO}_{4}$ fertilizer application $\left(\mathrm{g} \mathrm{L}^{-1}\right)(\mathrm{B})$} \\
\hline 0 & 8 & 8 & 8 \\
\hline 2 & 8 & 8 & 8 \\
\hline 4 & 8 & 8 & 8 \\
\hline 6 & 8 & 8 & 8 \\
\hline 8 & 8 & 8 & 8 \\
\hline 10 & 8 & 8 & 8 \\
\hline Average (B) & 8 & 8 & \\
\hline F-test: $\mathrm{A}$ & ns & & \\
\hline $\mathrm{B}$ & ns & & \\
\hline $\mathrm{A} \times \mathrm{B}$ & ns & & \\
\hline CV. (\%) & 2.44 & & \\
\hline
\end{tabular}

Note. $\mathrm{ns}=$ non-significantly different at $\mathrm{P}>0.01$

\subsubsection{Fresh Weight of Pepper Seedling}

The results showed that seed preparation methods were significantly different and seed primed gave the fresh weight higher than non-seed primed (Table8). $\mathrm{Ca}_{2} \mathrm{SiO}_{4}$ fertilizer application at a rate $4 \mathrm{~g} \mathrm{~L}^{-1}$ was significantly different and gave to trend the fresh weight of pepper seedling (Table8). While, relationship between factor A with factor $\mathrm{B}$ were significantly different that seed-primed with application rate of $\mathrm{Ca}_{2} \mathrm{SiO}_{4}$ fertilizer at $4 \mathrm{~g} \mathrm{~L}^{-1}$ gave to trend the high of fresh weight of pepper seedling (Table8).

Table 8. Fresh weight $(\mathrm{g})$ of pepper seedling (experiment 2$)$

\begin{tabular}{|c|c|c|c|}
\hline \multirow[t]{2}{*}{ Factors } & \multicolumn{2}{|c|}{ Seed preparation methods (A) } & \multirow{2}{*}{$\begin{array}{l}\text { Average } \\
\text { (A) }\end{array}$} \\
\hline & Non- seed primed & seed primed & \\
\hline \multicolumn{4}{|l|}{$\mathrm{Ca}_{2} \mathrm{SiO}_{4}$ fertilizer application $\left(\mathrm{g} \mathrm{L}^{-1}\right)(\mathrm{B})$} \\
\hline 0 & $2.61 \mathrm{~d}$ & $2.73 \mathrm{~d}$ & $2.67 \mathrm{C}$ \\
\hline 2 & $3.58 \mathrm{ab}$ & $3.79 \mathrm{ab}$ & $3.69 \mathrm{~A}$ \\
\hline 4 & $3.52 \mathrm{ab}$ & $3.88 \mathrm{a}$ & $3.70 \mathrm{~A}$ \\
\hline 6 & $3.64 \mathrm{ab}$ & $3.47 \mathrm{~b}$ & $3.56 \mathrm{AB}$ \\
\hline 8 & $3.08 \mathrm{c}$ & $3.66 \mathrm{ab}$ & $3.37 \mathrm{~B}$ \\
\hline 10 & $3.52 \mathrm{ab}$ & $3.73 \mathrm{ab}$ & $3.62 \mathrm{~A}$ \\
\hline Average (B) & $3.32 \mathrm{~B}$ & $3.54 \mathrm{~A}$ & \\
\hline F-test : A & $* *$ & & \\
\hline $\mathrm{B}$ & $* *$ & & \\
\hline $\mathrm{A} \times \mathrm{B}$ & $*$ & & \\
\hline CV. (\%) & 6.69 & & \\
\hline
\end{tabular}

Note. $* *=$ significantly different at $\mathrm{P}<0.01, *=$ significantly different at $\mathrm{P}<0.05$

\subsubsection{Dry Weight of Pepper Seedling}

The results showed that seed preparation methods significantly different and seed primed gave the dry weight higher than non-seed primed (Table9). $\mathrm{Ca}_{2} \mathrm{SiO}_{4}$ fertilizer application at a rate $2 \mathrm{~g} \mathrm{~L}^{-1}$ was significantly different and gave to trend the dry weight of pepper seedling (Table9). While, relationship between factor A with factor B were non significantly different of dry weight of pepper seedling (Table9). 
Table 9. Dry weight (g) of pepper seedling (experiment 2)

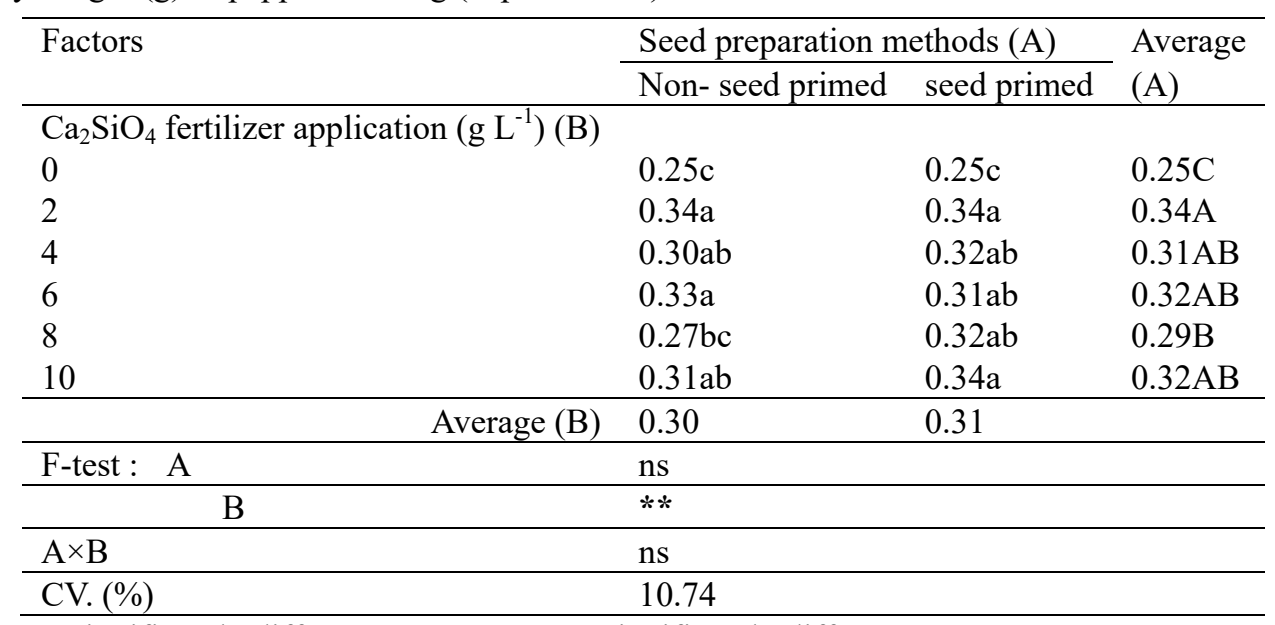

Note. $\mathrm{ns}=$ non-significantly different at $\mathrm{P}>0.01, * *=$ significantly different at $\mathrm{P}<0.01$

\subsubsection{Total Silicon Content in Pepper Seedling}

Our treatments results demonstrated that in total silicon, seed preparation methods the results showed that was non significantly different of total silicon in pepper seedling (Table10). In addition, $\mathrm{Ca}_{2} \mathrm{SiO}_{4}$ fertilizer application at a rate $2 \mathrm{~g} \mathrm{~L}^{-1}$ was significantly different and gave to trend the total silicon in pepper seedling (Table10). While, relationship between factor $\mathrm{A}$ with factor $\mathrm{B}$ were non-significantly different of the Total silicon in pepper seedling (Table10).

Table 10. Total silicon content $\left(\mathrm{mg} \mathrm{kg}^{-1}\right)$ in pepper seedling (experiment 2)

\begin{tabular}{|c|c|c|c|}
\hline \multirow[t]{2}{*}{ Factors } & \multicolumn{2}{|c|}{ Seed preparation methods $(\mathrm{A})$} & \multirow{2}{*}{$\begin{array}{l}\text { Average } \\
\text { (A) }\end{array}$} \\
\hline & Non- seed priming & seed priming & \\
\hline \multicolumn{4}{|l|}{$\mathrm{Ca}_{2} \mathrm{SiO}_{4}$ fertilizer application $\left(\mathrm{g} \mathrm{L}^{-1}\right)(\mathrm{B})$} \\
\hline 0 & $0.54 \mathrm{e}$ & $3.10 \mathrm{de}$ & $1.80 \mathrm{c}$ \\
\hline 2 & $11.10 \mathrm{ab}$ & $0.13 .30 \mathrm{a}$ & $12.00 \mathrm{a}$ \\
\hline 4 & $0.69 \mathrm{bcd}$ & $8.60 \mathrm{abc}$ & $7.80 \mathrm{~b}$ \\
\hline 6 & $5.9 \mathrm{~cd}$ & $8.50 \mathrm{abc}$ & $7.20 \mathrm{~b}$ \\
\hline 8 & $7.9 \mathrm{bc}$ & $8.80 \mathrm{abc}$ & $8.40 \mathrm{~b}$ \\
\hline 10 & $8.7 \mathrm{abc}$ & $9.10 \mathrm{abc}$ & $8.90 \mathrm{~b}$ \\
\hline Average (B) & 6.90 & 8.60 & \\
\hline F-test : A & ns & & \\
\hline $\mathrm{B}$ & $* *$ & & \\
\hline $\mathrm{A} \times \mathrm{B}$ & ns & & \\
\hline 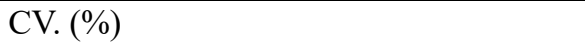 & 28.62 & 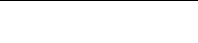 & \\
\hline
\end{tabular}

\section{Discussion}

Experiment 1, the effect of $\mathrm{Ca}_{2} \mathrm{SiO}_{4}$ fertilizer applied in pepper by mixed in growing media. The results showed that seed-primed with $\mathrm{Ca}_{2} \mathrm{SiO}_{4}$ fertilizer application at a rate $2 \mathrm{~g} \mathrm{~L}^{-1}$ was significantly different and gave the plant height, fresh weight and dry weight higher than non-seed-primed. In addition, $\mathrm{Ca}_{2} \mathrm{SiO}_{4}$ fertilizer application in soil was significantly different plant height, fresh and dry weight and $\mathrm{Si}$ content in plant. By the time, $\mathrm{Ca}_{2} \mathrm{SiO}_{4}$ fertilizer application at a rate $120 \mathrm{~kg} \mathrm{ha}^{-1}$ gave to trend the high of plant height, fresh and dry weight and $\mathrm{Si}$ content in plant. While, relationship between seed preparation methods with application rate of $\mathrm{Ca}_{2} \mathrm{SiO}_{4}$ fertilizer were significantly different that seed-primed with application rate of $\mathrm{Ca}_{2} \mathrm{SiO}_{4}$ fertilizer at $120 \mathrm{~kg} \mathrm{ha}^{-1}$ gave to trend the high of plant height, fresh and dry weight and Si content in plant. In addition, experiment 2, the effect of $\mathrm{Ca}_{2} \mathrm{SiO}_{4}$ fertilizer application in pepper by foliar method the results showed that seed-primed by $\mathrm{Ca}_{2} \mathrm{SiO}_{4}$ fertilizer application at a rate $2 \mathrm{~g} \mathrm{~L}^{-1}$ was significantly different and gave the plant height, and fresh weight 
higher than non-seed primed. In addition, seed-priming and non-seed priming was not significantly different of plant leaf number, dry weight and total $\mathrm{Si}$ content in plant. $\mathrm{Ca}_{2} \mathrm{SiO}_{4}$ fertilizer application by foliar method was significant different of seedling fresh weight, seedling dry weight and total $\mathrm{Si}$ content in plant. $\mathrm{Ca}_{2} \mathrm{SiO}_{4}$ fertilizer application by foliar method at a rate $2 \mathrm{~g} \mathrm{~L}^{-1}$ gave to trend the seedling fresh weight, seedling dry weight and total $\mathrm{Si}$ content in plant. However, relationship between seed preparation methods with application rate of $\mathrm{Ca}_{2} \mathrm{SiO}_{4}$ fertilizer application by foliar method were not significantly different at $\mathrm{P}<0.01$. Seed-primed with $\mathrm{Ca}_{2} \mathrm{SiO}_{4}$ fertilizer application at a rate $2 \mathrm{~g} \mathrm{~L}^{-1}$ by foliar method gave to trend the high of plant height, leaf number, seedling fresh weight, seedling dry weight and total Si content in plant. Each experiment, it was found that seed primed increased the growth rate of pepper seedling higher more than non-seed primed. Which was in accordance with the finding of primed seeds stimulate and enhanced germination speed and uniformity of seeds (McDonald, 2000). In additions, Hanson (1984) reported the Ca stimulated seed germination and is the cofactor of amylase enzyme. It helped digestion of starch in sperm seeds of a smaller and to promoted seed germination. In addition, Korhmaz (2005) reported that primed sweet pepper seed with $\mathrm{KNO}_{3}$ with $0.1 \mathrm{mM}$ acetylsalicylic acid gave the good seedling more than non-primed seed. All of above seed primed gave the growth rate and total Si content more than non-seed primed. Moreover, each experiments the results showed that seed primed by $\mathrm{Ca}_{2} \mathrm{SiO}_{4}$ fertilizer application at a rate $120 \mathrm{~kg} \mathrm{ha}^{-1}$ (mixed in growing media) and $\mathrm{Ca}_{2} \mathrm{SiO}_{4}$ fertilizer application at a rate $2 \mathrm{~g} \mathrm{~L}^{-1}$ (foliar method) were gave to trend the growth rate of pepper seedling. It found that $\mathrm{Ca}_{2} \mathrm{SiO}_{4}$ fertilizer used in this experiment was component as $\mathrm{Si}$ and $\mathrm{Ca}$. Then, $\mathrm{Si}$ and $\mathrm{Ca}$ gave the cell membrane is strong (Epstein \& Bloom, 2005) and Si fertilizer is applied to crops in several countries for increased productivity and sustainable production. Which, plants uptake $\mathrm{Si}$ in the form of silicic acid, which is transported to the shoot, and after loss of water, it is polymerized as silica gel on the surface of leaves and stems. enhance the strength of the tissue (Ma \& Takahashi, 2002) consist of Si accumulated in the cell wall there is characteristic lamination (Silica layer) influence to plant leaves are strong (Epstein \& Bloom, 2005). Due to plants uptake Si to cell, Si changes to the solid from of Si in cell wall of plant. It can be improve the structure of cell wall and stronger resistance to disease and insect infestation (Marschner, 1995). In addition, Si can increase watering conditions, and it can also improve the growth of this crop in drought conditions by maintaining high leaf areas to insure high assimilatory capability, thickening leaves which are beneficial to reduce the transpiration loss of water (increasing the thickness of leaves) leaf erectness, haulm stability and lodging. Also, $\mathrm{Ca}_{2} \mathrm{SiO}_{4}$ used in this experiment was component as magnesium (Mg). Thus, $\mathrm{Mg}$ is composition of photosynthesis in plants as a result increased efficiency of photosynthesis (Gong et al., 2003). Then, plant also encourages the highest pepper seedlings growth. However, the utilization of $\mathrm{Ca}_{2} \mathrm{SiO}_{4}$ fertilizer application at a high dose in the pepper seedling could decrease plant growth.

\section{Conclusion}

Utilization of $\mathrm{Ca}_{2} \mathrm{SiO}_{4}$ fertilizer application by seed primed with $\mathrm{Ca}_{2} \mathrm{SiO}_{4}$ fertilizer application by mixed in growing media at a rate $120 \mathrm{~kg} \mathrm{ha}^{-1}$ gave the good plant growth and total silicon in plant. And $\mathrm{Ca}_{2} \mathrm{SiO}_{4}$ fertilizer application by seed primed with $\mathrm{Ca}_{2} \mathrm{SiO}_{4}$ fertilizer application by foliar at a rate $2 \mathrm{~g} \mathrm{~L}^{-1}$ gave the highest of plant growth and total silicon in plant. By the time, $\mathrm{Ca}_{2} \mathrm{SiO}_{4}$ fertilizer application can be employed for enhancing plant growth of pepper seedling and increasing $\mathrm{Si}$ content in plant.

\section{Acknowledgement}

We gratefully acknowledge the Graduate School at Kasetsart University for financial support.

\section{References}

Department of Agriculture (2015). The reported data of crop production annually2013/2014. Retrieved from http://production.doae.go.th/report/report_main2.php?report_type=1

Epstein, E., \& Bloom, A. J. (2005). Minerals Nutrition of Plants: Principles and Perspective. (2nd Ed.) Sinauer Associated, Inc. p. 400. http://dx.doi.org/10.1002/jpin.19721320211

Gong, H., Chen, K., Chen, G., Wang, S. \& Zhang, C. (2003). Effects of silicon on growth of wheat under drought. Journal of Plant Nutrition, 26, 1055-1063. http://dx.doi.org/10.1081/PLN-120020075

Korkmaz, A. (2005). Inclusion of acetyl salicylic acid and methyl jasmonate into the priming solution improves low-temperature germination and emergence of sweet pepper. Horticultural Science, 40, 197-200.

Kunlinda, T., Thongchai, M., Pornpairin, R., \& Suphachai, A. (2014). Utilization of calcium silicate on growth and yield quality of sweet pepper in hydroponics system. KHON KAEN Agriculture Journal. 42 SUPPL.3.

Ma, J. F., Miyake, Y., \& Takahashi, E. (2001). Silicon as a beneficial element for crop plants. In: Silicon in Agriculture, Eds. L. E. Datnoff, G. H. Snyder and G.H. Korndorfer, 17-39. 
Ma, J., \& Takahashi, E. (2002). Soil Fertility and Plant Silicon Research in Japan. Elsevier Science. Amsterdam, London, Boston.

Ma, J., \& Yamaji, N. (2006). Silicon uptake and accumulation on higher plants. TRENDS in Plant Science, 11, 392-397. http://dx.doi.org/10.1016/j.tplants.2006.06.2007

McDonald, M. B. (2000). Seed priming. pp. 287-325. In B. Michael, \& J. D. Bewley, Eds. Seed Technology and its Biological Basis.Sheffield Academic Press, England.Gerhard, F. 2006.The seed biology place. Retrieved from http://www.seedbiology.de/seedtechnology.asp

Nayer, P. K., Misra, A. K., \& Patnaik, S. (1975). Rapid micro determination of silicon in rice plant. Plant and Soil, 42, 491-494. http://dx.doi.org/10.1007/BF00010025

Neumann, D., \& Nieden, U. (2001). Silicon and heavy tolerance of higher plants. Phytochemistry, 56, 685-692. http://dx.doi.org/10.1016/S0031-9422(00)00472-6

\section{Copyrights}

Copyright for this article is retained by the author(s), with first publication rights granted to the journal.

This is an open-access article distributed under the terms and conditions of the Creative Commons Attribution license (http://creativecommons.org/licenses/by/4.0/). 